\title{
ITALIAN COMMERCIAL LITIGATION: AN OUTLINE ${ }^{*}$
}

\author{
Michele de MEO, the Law Firm "de Meo \& Associati" \\ 59, 00186-Via Giulia, Rome, Italy \\ E-mail: demeolawfirm@gmail.com
}

The article contains the outline of the commercial litigation implemented in Italy taking into account the relevant amendments and changes adopted with the aim of rendering a "faster" justice. The author describes the Italian judicial system which involves courts of first instance (Giudice di Pace/Tribunale), the Court of Appeal (Corte d'Appello), and the Supreme Court or the Court of Cassation (Corte di Cassazione), indicating the statutorily prescribed criteria for referring a specific category of cases to the jurisdiction of each of those. The author dwells on the stages of civil proceedings, which include: pre-trial hearings, civil proceedings and judgment, appeal and cassation stages, as well as enforcement of judgments and orders. The special attention is paid for the procedure of the recognition and enforcement of foreign judgment and arbitration awards used in Italy. The author notes the tendency for a gradual replacement of the most of the old bilateral treaties in Europe by the European Regulations, at least in civil and commercial matters.

Keywords: Italy, judicial procedure, commercial litigation, civil proceedings, system of courts, recognition of foreign judgments, enforcement of foreign judgments.

\section{РАЗРЕШЕНИЕ ХОЗЯЙСТВЕННЫХ СПОРОВ В ИТАЛИИ: КРАТКИЙ ОБЗОР}

\author{
Де МЕО Мишеле, адвокатская контора «Де Мео и Партнеры» \\ Италия, г. Рим, 00186-Виа Джулия, 59 \\ E-mail: demeolawfirm@gmail.com
}

В статье представлен краткий обзор применяемой в Италии процедуры судопроизводства по делам, вытекающим из хозяйственных споров, с учетом последних изменений законодательного регулирования в этой сфере в целях обеспечения «ускоренного» судопроизводства по данной категории гражданских дел. Автор описывает систему судов Италии, включающую суды первой инстанции (Giudice di Pace / Tribunale), Апелляционный суд (Corte d'Appello) и Bерховный суд (Corte di Cassazione), с указанием законодательно установленных критериев отнесения определенной категории дел к подсудности и подведомственности каждого из судов. Подробно рассматриваются стадии гражданского судопроизводства, а именно: предварительное судебное разбирательство, рассмотрение хозяйственного спора судом и вынесение решения, апелляционное и кассационное судопроизводство, а также порядок исполнения судебных решений и приказов суда. Отдельное внимание уделяется применяемому в Италии порядку признания и исполнения решений зарубежных арбитражных и третейских судов. Автором отмечается тенденция к постепенному замещению ранее используемых двухсторонних международных договоров руководящими директивами ЕС при регулировании вопросов, связанных с признанием и исполнением решений зарубежных судов по гражданским и коммерческим делам.

Ключевые слова: Италия, судопроизводство, система судов, гражданский процесс, разрешение хозяйственных споров, признание решений зарубежных судов, исполнение решений зарубежных судов.

DOI: $10.12737 / 20579$

\section{Structure of the Italian Courts}

1.1. Courts where commercial litigation is initiated. The Italian judiciary system has been structured as a unit in the sense that the Constitution prohibits the setting up

* On the same subject see: de Meo M., Italian Commercial Litigation. Encyclopedia of International Commercial Litigation, 2007, ed. by the Hon. Sir Anthony Colman and published by Kluver Law International and updated annually. of special courts; it follows therefore that almost all civil claims including those listed under the specific section herein are dealt with by the ordinary civil courts. In recent years several changes have been and are being adopted with the aim of rendering a "faster" justice.

There is also one further major judicial system, which concerns the public administration, both in relation to disputes within its organization and in relation to disputes where the administration in its "public law" capacity deals with citizens. This system is based on a number of 
Regional Administrative Courts which are evenly located throughout the national territory and which constitute an entirely autonomous system outside the scope of this summary.

Constitutional law forbids the creation of special courts but allows the setting up of specialized sections in the ordinary courts. The ordinary civil courts are: 1) Court of First Instance (Giudice di Pace/Tribunale); 2) Court of Appeal (Corte d'Appello); 3) Supreme Court or Court of Cassation (Corte di Cassazione).

The Courts of First Instance as well as the Court of Appeal consider both facts and law whereas the Court of Cassation is empowered to consider only the correct application and interpretation of the law.

1.2. Limits on the Courts' jurisdiction. The jurisdiction of the Giudice di Pace encounters its first limitation in relation to the value of the claim; he can decide only upon disputes with a limited value and disputes involving the circulation of vehicles or boats with a value up to 15,493.71 Euro. If the dispute exceeds these values or if the value of the dispute cannot be ascertained, the jurisdiction rests with the Tribunale.

In order to ascertain the value of the dispute, account will be taken of the claim for capital and interest together with any penalties which may be imposed, alternatively of any greater counterclaim from the defendant. If there are several plaintiffs or defendants the value of the dispute is derived from the total aggregate figure.

The Giudice di Pace has exclusive jurisdiction, whatever the amount of the claim, in relation to certain enforcement and attachment proceedings, boundary disputes, and certain eviction proceedings; the Tribunale has jurisdiction in relation to the status and capacity of persons and the authenticity of documents; and the Court of Appeal in relation to recognition and enforcement of foreign judgments, whatever the state of origin.

The Italian courts are also limited geographically in terms of which matters they may deal with. Essentially, the Giudice di Pace has jurisdiction over a small geographical area and in any event over a particular town, whereas the jurisdiction of the Tribunale usually embraces a geographical area which corresponds to a "province", and the Court of Appeal's jurisdiction which may extend from one large province to an entire region. There is only one Court of Cassation for the whole of Italian territory and it is located in Rome.

The rules which determine the territorial jurisdiction, and are expressed in Italian legal jargon by the words "territorial competence"; this is the power vested in one Court rather than in another in the territory of the Republic. The rules are numerous and can be summarized as follows:

the general "Forum" in relation to individuals is that of the place where the defendant resides or is domiciled or, if these are unknown, of the defendant's place of abode;

the general "Forum" in relation to companies and corporations is that of the place where the defendant company has its "seat", or the place where the company has an address, together with a representative officer with authority to sue and be sued and to accept service of proceedings for and on behalf of the company;

the alternative "Forum" in relation to disputes concerning obligations arising out of contracts, quasicontracts and tort is that of the place where the obligation in question arose or should have been performed;

the "Forum" in relation to disputes between company members or co-owners is that of the court of the place where the company has its seat or of the court of the place where the jointly owned property or the majority of the jointly owned properties is.

Italian citizens may be sued before the Italian courts provided there is an element which links the dispute to the Italian court, whether that be contractual or tortious, whereas the simple fact that the plaintiff is an Italian citizen is not sufficient to establish the Italian court's jurisdiction.

\section{Jurisdiction of the Italian Courts in general}

With particular reference to the principles upon which the Italian courts exercise jurisdiction over a defendant who is not domiciled, resident or present within the territory, a number of aspects and rules must be considered.

2.1. Private international law. The following are among the most important circumstances in which Italian courts may exercise jurisdiction:

i) where the defendant is domiciled or resident in Italy or has authorized a representative to act on his behalf in legal proceedings in accordance with certain provisions of the Code of Civil Procedure, or other specific case provided by law; or

ii) where the parties have agreed between themselves and expressly submitted to the Italian jurisdiction in writing; or

iii) if the defendant appears before the Italian courts and fails to raise the lack of jurisdiction; or

iv) regarding precautionary remedies, if the measures are to be executed in Italy or the Italian court has jurisdiction on the merits; or

v) in the event of a dispute concerning title to real property located in Italy; or

vi) as alternative to the defendant's jurisdiction, in relation to contractual, quasi-contractual or tortious obligations arising or to be performed in Italy;

vii) for other matters not covered above by application of the principles of territorial competence.

When seeking to exercise jurisdiction of the Italian courts, the relevant criterion must be ascertained when the claim is brought. Lack of jurisdiction may only be raised in the court proceedings up to the stage of the first defence by a defendant who has not expressly or impliedly accepted Italian jurisdiction. Jurisdiction may also be raised independently by the presiding judge at any stage of the proceedings, provided the defendant has not entered 
an appearance, the claim related to immoveable property situated abroad, or if Italian jurisdiction is precluded by international law.

The criteria apply both to individuals and corporations in which case reference must be made to the "seat" of the company. Since all foreign corporations which operate directly in the Italian territory must set up a representative office with a representative having authority to act on their behalf in judicial proceedings, in practical terms a foreign corporation which operates directly in Italy (but not merely through an agent) can be sued in Italy.

Italian principles of conflict of laws provide that foreign law may be ascertained by the judge of first instance acting on his own initiative. To this end, the judge may make use of the instruments provided for in international conventions, rely on information supplied by the Italian Ministry of Justice, or make specific requests for details from experts or specialized institutions. The judge may also ask the parties to assist. In such cases, a certified copy of the relevant extract from a statute or other official text of law, together with a supporting opinion or affidavit from a local lawyer are usually considered sufficient evidence for these purposes, and they will be lodged with the court's bundle in the same way as any other documentary evidence.

When in the course of proceedings, a prior pending suit between the same parties on the same issue and same ground before a foreign court comes to light, the Italian judge must suspend the case if of the belief that the foreign proceedings could have an effect within Italy. If the foreign judge declines jurisdiction or the measure is not recognised by the Italian system, the Italian judge continues with the case before him. Where the two parallel proceedings are connected then the Italian judge has discretion whether to stay the proceedings.

2.2. Jurisdiction and enforcement of judgments in civil and commercial matters. The European law prevails over any national conflicting provision. The Brussels Convention continues for some territories which are excluded from the new EU Regulation. The Lugano Convention also continues between Italy and States outside the EU which adhere to that Convention, such as Switzerland.

The Brussels Regulation applies to all civil and commercial matters except: revenue, customs, and administrative matters; the legal status of individuals; rights in matrimonial property, wills and succession; bankruptcy, winding-up proceedings involving insolvent companies or other legal persons, judicial arrangements, compositions, and analogous proceedings; social security; and arbitration. Some of these mentioned exceptions are progressively being covered by other European Regulations or similar instruments.

The Brussels Regulation introduces the general rule of a "basic jurisdiction" which is that of the domicile of the defendant; in other words the nationality of the defendant is irrelevant and a defendant must be sued in the courts of the State in which he is domiciled, provided that State is a party to the Regulation and subject to any alternative grounds of special jurisdiction being available. The general rule does not apply either in cases of exclusive jurisdiction or prorogation choice. Submission to the jurisdiction by unconditional entry of appearance also waives any right to insist on the general rule or alternative jurisdiction.

The concept of domicile used in the Regulation can be defined as being equivalent, in relation to individuals, to genuine residence and in relation to corporations to the place where the company has its seat.

The definition of "basic jurisdiction" mentioned above is mitigated by cases of special jurisdiction whereby a person domiciled in a Member State may be sued:

i) in matters relating to a contract in the court of the place of performance of the obligation in question; this is further elaborated for sale of goods to the place of delivery, and for services to the place of provision of the services;

ii) in matters relating to maintenance in the courts of the maintenance creditor, or if ancillary to status proceedings, then in that jurisdiction (but not solely on grounds of nationality);

iii) in matters relating to tort, delict or quasi-delict in the courts of the place where the harmful event occurred or is feared;

iv) in a civil claim based on criminal proceedings in that same court if it has jurisdiction to entertain civil proceedings;

v) in matters relating to disputes concerning the operation of a branch or agency, before the judge of the place where such branch or agency is located;

vi) in "trust" matters in the court of the State in which the "trust" is domiciled;

vii) for salvage of a cargo or freight, in the court seised for related arrest, bail or security.

\section{Procedure before a Court of first instance}

3.1. Pre-trial definition of issues. Under Italian civil procedure there is no distinction between pre-trial and trial stages. This is so because there is no such defined stage as a trial stage. The pre-trial stages or examination proceedings include activities which common law lawyers would expect to find at the trial, and at the end of the pretrial stage all that remains to be done is for the parties to lodge with the court the pleadings, the conclusions and the supporting documents so that the judge may consider the matter and render his or her decision in due course. Almost all the procedure is in writing and certainly nothing which has not been reproduced in writing is considered by the judge when he renders his decision.

The proceedings are usually commenced as follows: as a preliminary matter, the plaintiff should ensure that the claim is not statute-barred.

The plaintiff, having examined his legal position in relation to jurisdiction, time limits, law of the contract and factual issues, must, before any official court activity is begun by his lawyers, execute a power of attorney in 
favour of the lawyer in relation to the proceedings which are to be commenced. The importance of this document cannot be overstated because in its absence or if the document is dated with a date which is subsequent to that inserted in the court bundle there is a very real danger that all proceedings be null and void.

The first pleading on the part of the plaintiff must contain the indication of the parties the name and domicile or residence of the lawyers representing them and in the case of legal persons the names of those who represent them in the proceedings as duly authorized representatives. The pleading must also contain an indication of the subject-matter in relation to which redress is sought together with all the elements of fact and of law upon which the plaintiffs claim is based and in addition, if already available, an indication in the form of a list of the documents which the plaintiff intends to use and produce to the court together with any other necessary evidence.

Once the defendant has been served with the plaintiffs pleading he has, in practice, until the first hearing, and in some circumstances even beyond that, within which to enter an appearance. This is done by way of a formal pleading to which a counterclaim may be added and/or a request to join third parties. The plaintiff may then file a reply and the defendant a counter-reply and various other written pleadings may be exchanged during the proceedings. In ordinary circumstances the main issues are set out in the first pleadings from the plaintiff and from the defendant.

As already mentioned the procedure is characterized by its written form. It follows that all the pleadings, evidence and interlocutory applications must be reproduced in writing and lodged with the court to safeguard the principle that the opponent must always be given an opportunity to consider the arguments raised by the other side.

The procedure from the judge's point of view is as follows: the judge of first instance, who receives the court file from the President of the Tribunale or from the President of the section of the Tribunale to which the matter has been allocated, considers all the pleadings and applications made by the parties and, in general, has powers of initiative upon the procedure. He may rule upon those applications which would not cause the dispute to come to an end, such as applications in relation to interim relief or admissibility of evidence. The purpose of this stage of the procedure, is the preparation of the case for its decisory stage. The judge of first instance will now in most cases also make the final ruling. In cases concerning bankruptcy, status and capacity of persons, corporate relations and in other limited instances the court file will be transmitted to the panel of three judges for their final ruling.

3.2. Pre-trial hearings. There is no such defined distinction between a pre-trial and a trial stage, since what would be easy to classify as a trial stage, namely that part of the proceedings which takes place at the end of the "pre-trial" stage, happens in fact behind closed doors and no further legal activities are allowed. That stage which is classified under Italian civil procedure as the "pre-trial" stage does, in fact, contain activities such as the exchange of pleadings, the taking and exchange of evidence, interlocutory applications in relation to procedural aspects or to interim relief, the examination of witnesses and the consideration of the relevance and admissibility of evidence.

All of the pre-trial stage, is conducted under the supervision of the "judge of first instance" and therefore the hearings take place before him. The number of hearings which may occur in this stage, and the number of matters to which such hearings may relate, is substantial. At the first hearing before the "judge of first instance", the judge checks whether the parties have duly appeared and if necessary invites them to complete the pleadings or other documents which in his opinion require adjustments. In addition, on checking the papers he may find that a party is not duly represented by his lawyer in that the lawyer lacks the necessary power of attorney, in which case the judge may fix a term within which the formal defect has to be put right. Since it is usual for the defendant to file his defence and supporting documents at the first hearing it is also usual for the plaintiff to apply for an adjournment so that he may examine the pleadings and documentation filed by the defendant. The judge will also consider in this first hearing any preliminary issues raised either in the pleadings or orally, but then reproduced in writing at the hearing.

At the second hearing the plaintiff will be given an opportunity to adjust its pleadings in connection with the defence and counterclaim (if any) raised by the defendant and filed with the court at least 20 days earlier. If requested by the parties, the judge may allow a maximum of another 30 days for both parties to put their papers in order.

In general, the decisions of the pre-trial judges are orders. There is no immediate right of appeal against these orders during the proceedings, except for those instances in which the decision phase of the proceedings is handled by a panel of judges. In such cases a party may take immediate recourse to the panel of judges by requesting a review of the order. If the panel of judges decides the matter in favour of the party seeking review of the order, then the judge of first instance is ordered to continue with the case in light of the panel's decision.

In cases where the final decision is to be rendered by a panel of judges, the judge of first instance will hear and determine issues of jurisdiction, territorial jurisdiction, defective service of proceedings, time bar issues, and any other preliminary objections which by law have to be raised either at the first hearing or in the first defensive pleading in the event that this be filed subsequently to the first hearing. In such cases, the power of the judge of first instance is limited to deciding orders on procedural issues relating to the conduct of the enquiry phase and only the panel of judges has the authority to issue orders that bring the dispute to an end (whether on preliminary matter or on the merits). 
3.3. Pre-trial discovery and depositions. The main rules governing this area of procedure are those which relate to the burden of proof and to the duty to discover documents or witnesses evidence. The burden of proving a specific fact, or that from such a fact specific consequences derive, lies with the party which makes the allegation. There is no duty on a party to disclose documents or witness evidence which are unfavourable to its case; does of course this not mean that deliberate lying to the judge or to the opponent is permitted.

The documents and witnesses evidence upon which a party wishes to rely are lodged with the court and therefore exchanged between the parties before the decisory stage is reached. Whenever new documents are put forward by a party, whether that be very early in the proceedings or when the "pre-trial" stage is nearly concluded, the party against which the documents are produced must always be given an opportunity to reply by producing other documents or by commenting in a pleading.

The rules regarding forced discovery refer specifically to certain classes of documents which corporations must possess by law and to certain types of disputes which arise from the winding-up of the corporation or the joint ownership of assets. In this case the judge of first instance, may order the opponent or a third party to exhibit a document or any other thing the production of which he deems useful. In order to do so the judge will issue an order fixing the time, place and way in which the documents or things will be produced and if expenses are to be sustained these will have to be advanced by the party making the application.

The party requesting production of a document has to discharge a fairly heavy burden in that the judge must be satisfied that the document requested contains the evidence of the fact in dispute. Accordingly an application for discovery made to explore only whether the document contains such evidence is unlikely to succeed.

There is a particular procedure which can be carried out on application by a party to future proceedings even before proceedings are in fact commenced. This preliminary discovery concerns the examination of witnesses or the inspection of places or of things (in order to ascertain their quality and condition), in order to prevent the dissipation of relevant evidence. The application must be lodged with the judge who would have jurisdiction on the merits of the case, save that in cases of exceptional urgency it may be lodged with the Court of the place where the evidence must be taken.

3.4. Pre-trial experts' reports. Any evidence which has been allowed by the judge as admissible and relevant is indirectly exchanged by the parties before the decisory stage of the trial; this therefore includes experts' evidence in the form of reports or statements whenever experts are appointed by the parties in relation to technical issues.

A distinction must, however, be drawn between the two ways in which an expert may be involved in proceedings. A party may appoint an expert in order to obtain a report which is filed as any other documents with the pleadings, but such report possesses only a limited probative value in that the judge may freely consider its contents to form his view. The position is quite different in those instances where the judge has appointed a court's expert, in which case he must also give the parties an opportunity to appoint their own experts (the parties have in fact a right to do so). The party's expert so appointed has the right to participate in all the hearings and procedural activities in which the court's expert participates and to make his or her own comments and observations.

3.5. Pre-Trial investigatory procedures. Whenever a court's expert is appointed by the judge, he may attend all the pre-trial hearings and the trial hearing if so requested by the judge or by the panel, and carry out all those activities which are requested by the judge of first instance. In order to be in a position to answer the judge's queries adequately the court's expert may, of his own initiative, enquire upon any relevant facts provided he does not enquire upon or produce evidence of facts which the parties have the burden of proving. The court's expert may also request information from third parties of his own initiative but if the third party does not comply with the request spontaneously the expert has no alternative but to obtain authority from the judge to renew his request.

3.6. Trial dates and duration. Once the pre-trial stage is concluded the judge commences the decisory phase by transmitting the court's bundle of documents to the panel of judges for the trial hearing and subsequent decision.

The days of the judicial calendar which are earmarked for trial hearings are fixed at the beginning of the judicial year by the Chief Justice of the Court and the actual date of the hearing is therefore ascertained by the judge of first instance when commencing the decisory phase. In cases where the decisory phase is before a judicial panel, the date of the trial hearing is pronounced on the day the judge of first instance transmits the court bundle to the panel.

An average waiting time for a commercial case from the hearing when the parties summarize their conclusions and the judge of first instance makes a decision or transfers the case to the panel, to trial date, is 12 to 18 months. The waiting time from the hearing fixed for the trial to the time when judgment is actually issued by the court is not much shorter.

\section{Appeals}

The proper "Appeal" and the "Petition for Cassation" are but only two of a number of remedies which can be pursued by a party wishing to obtain a review of the judgment. All the possible remedies can be listed as follows: (a) Appeal, (b) Petition for Cassation, (c) Application for review on jurisdiction, (d) Applications for reconsideration ("revocation") of the judgment on specific grounds, and (e) Oppositions from third parties.

A first distinction may be drawn in relation to the list mentioned above between ordinary procedures and extraordinary procedures, the former being those 
which cannot be pursued against final judgments, and the latter those which can. The procedures listed (d) and (e) above are considered extraordinary procedures and the remaining ones as ordinary procedures. Among the ordinary procedures appeal is the only one which is of general application in that it may concern points of fact and points of law and may query a number of defects which a judgment may contain, whereas all the other remedies are specifically aimed at particular defects.

A brief description of what judgments or orders can be "appealed" against and within what time limit will help to clarify.

By way of an ordinary appeal, a party may seek review of a judgment of first instance rendered by a Giudice di Pace or by a Tribunale. The appeal from a judgment of a Giudice di Pace is lodged with the Tribunale having territorial jurisdiction on the matter, whereas the appeal from a judgment of a Tribunale is lodged with the Court of Appeal with jurisdiction on the same territory. The peremptory time limit within which to lodge the appeal and serve it to the opponent is 30 days from valid service of the judgment appealed against on the losing party. In any event the judgment cannot be appealed after one year from the date when it has been lodged with the court's clerk even if service has never been effected.

By way of a petition for Cassation to the Court of Cassation a party may seek review of appeal judgments or judgments of first instance in those cases in which no appeal is available. A judgment of the Tribunale may also be reviewed directly by the Court of Cassation where the parties agree to by-pass the ordinary appeal procedure. A petition for Cassation is never concerned with points of fact but only with points of law and the time limit within which to lodge and serve the petition upon the opponent is 60 days from the date when the judgment petitioned against was served upon the party. In the case of a petition for Cassation the same rule is applied as for appeals, namely that in any event no petition can be lodged after more than one year from the lodging with the inferior court of the judgment to be petitioned against.

By way of an application to the Court of Cassation (which is not a petition for Cassation) a party may apply to challenge the jurisdiction of the Italian ordinary court visa-vis a foreign judge or the administrative courts before a first instance judgment is rendered. A similar application to the Court of Cassation (which again is not a petition for Cassation) may be used to challenge the territorial jurisdiction of a court within the Italian territory.

The first of the two extraordinary remedies is the Application for Revocation and is heard by the same court which issued the judgment. Said court may not only set aside the judgment so challenged but also decide on the merits of the case which in this way is in fact reopened.

This form of application can be granted only in the presence of very unusual factual circumstances which, if not corrected, would cause a miscarriage of justice. The challenge may be brought against appeal judgments or judgments of first instance for which no appeal is allowed by law. Since the "new" judgment takes the place of that set aside, it can be made subject to a petition of Cassation but not again to an Application for Revocation.

The time limit within which to commence this procedure by serving the application and lodging a writ with the court is 30 days which period as a basic rule, begins to run from the time the original judgment was served upon the party. However, this basic rule has numerous exceptions.

By way of a Third party opposition whoever has not been a party to the proceedings may, in fairly exceptional circumstances, challenge any enforceable or even final judgments whenever that judgment causes prejudice to his rights or (though then the applicant can only be the assignee or a creditor of the party), whenever the judgment resulted from fraud or agreement by the parties to the applicant's detriment.

First instance or appeal judgments can be challenged in this way, and the challenge is brought by way of a writ to appear before the same court which issued the opposed judgment. If the opposition is successful the judgment which is then rendered can be in turn challenged by way of the same remedy which would have been available against the original judgment and therefore by way of an ordinary appeal or a petition for Cassation as the case may be. The procedure itself is that which applies to the Court before which proceedings are commenced and therefore to the Tribunale or to the Court of Appeal.

4.1. Appeal. Mention has already been made of the territorial jurisdiction in relation to the appeal procedure and of the time limit within which proceedings must be commenced; in relation to time limits and with particular reference to a possible cross-appeal if the appeal is lodged within the prescribed period but the cross-appeal is not so commenced, if the main appeal fails the cross-appeal cannot stand on its own and must be discontinued.

In general, the procedure on appeal, whether before the Tribunale or before the Court of Appeal, is identical to that which applies to proceedings of first instance before the Tribunale, save where specific rules are dictated by the Code of Civil Procedure. The principal procedural difference is that appeals are always decided by a panel of judges. The panel will nominate one of their number as a reporter to inform the panel about the proceedings which took place prior to the appeal.

As to what can be requested of the Court in appeal proceedings, the general rule is that the request must be confined to the issues raised and considered in the judgment appealed against. It follows that new claims are barred and if they are made they must be rejected by the court of its own initiative. By way of an exception to the rule, a claim for interest accrued or damages suffered after the judgment of first instance, is allowed, provided of course they relate directly to the issues raised in that judgment. On the other hand, a party may raise new defences which had not been raised in first instance 
proceedings and should always repeat the defences on the merits or the objections on procedural points which had been disregarded or rejected in the judgment of first instance otherwise they may be held as waived in the appeal proceedings.

The decision of the court is rendered in much the same way as the decision in first instance proceedings.

4.2. Petition for Cassation. A petition for cassation (ricorso per Cassazione) may not be pursued on the basis of issues of fact but only on points of law and only against appeal judgments or judgments of first instance which cannot otherwise be appealed or where the parties have agreed to proceed direct to the Court of Cassation.

The petition itself must contain the following: the name of the parties, details of the judgment petitioned against, a summary of the facts of the dispute, the reasons for which the petition is brought and an indication of the law upon which the petition is founded, and the power of attorney given to the lawyer, or a reference to it if given by way of a separate document. As a rule no new documents are allowed to be filed except those which are necessary to show that the petition or the defence to the petition are inadmissible.

The proceedings themselves are fairly straightforward in that there is no preliminary stage and the petition proceeds to be considered directly at the oral hearing. At the oral hearing one of the judges reports first on the proceedings in general, then the lawyers acting for the parties put their case to the judges and then the court retires in chambers to decide.

The judgment rendered by the court may be of three kinds: (a) to dismiss the petition, (b) to set aside the judgment petitioned against, (c) to return the dispute to a lower court. In cases (a) and (b) the decision of the Court of Cassation usually signifies an end of the dispute whereas in case (c) this is not so since the lower court would then be in charge of the proceedings and the action must be formally recommenced before such court within the time limit of one year after the judgment of the Court of Cassation has been filed.

\section{Judgment}

The rendering of a judgment is always reserved and therefore no judgment is issued at the final hearing.

Once the decision is reached in chambers by the judge of first instance or panel of judges, the judge or President of the panel signs the draft document which is then delivered to the clerk of the court who takes care of the typing. After the document has been typed it is returned to the judge of first instance or the panel for signature and then filed with the clerk of the court. In theory the original judgment should be lodged with the clerk within 30 days after the final hearing, but in practice this never happens and the delay may be substantial. Until the judgment is lodged with the clerk of the court after signature, the document remains an internal document and no effects derive from it.

Even when the judgment is rendered public by way of deposit with the clerk of the court it is not enforceable unless leave to enforce is given by the court (which is considered further herein), or until the deadline to appeal has expired. In order to cause time to run a further formality is required; the judgment must be served upon the judgment debtor on application by the winning party, and service must be effected upon the lawyer representing the losing party unless the party had appeared in the proceedings in person. It must not be forgotten that judgments are subject to two registration taxes, the first of which is always due and calculated on the value of the asset or dispute considered in the judgment, whereas the second is not always payable and varies according to the circumstances. As the matter is very complicated advice should always be obtained before commencing proceedings.

The judgment itself must contain three essential elements:

(a) a concise narrative of the main points of fact and of law raised by the parties or by the judge of first instance during the proceedings and upon which the reasoning of the court is based;

(b) the "reasons" for which the court has reached its conclusions, based upon the relevant factual and legal issues. The reasons should contain an indication as to which of the points have been accepted or rejected and as to the rules of law which have been applied; a specific indication of the actual substantive or procedural rules applied is not, however, absolutely necessary;

(c) the decision taken by the court, which consists of an order to do or not to do something or of a declaration of the existence or non existence of a legal relationship.

The Italian courts' precedents are not a binding authority nor are they irrelevant, however, precedents can be considered as persuasive and the degree of persuasiveness varies depending on whether the judgment contributes to form an established view and on whether it is issued by a Judge of First Instance, or Court of Appeal or Court of Cassation. The reason for the absence of the rule of precedent (stare decisis) is that the Italian judge can only apply the law and does not make it and therefore each case stands strictly on its own merits.

The rule is that a court is not bound to construe the law in accordance with the construction adopted by other courts or even by the same or higher court. However, previous decisions cannot be ignored altogether and if there is no reason to depart from the reasoning adopted in other judgments, such reasoning will be followed. In particular, since one of the duties of the Court of Cassation is to "ensure the precise performance and the uniform construction of the law", judgments of this court are highly persuasive and it would take a great deal of reasoning from a lower judge in order to depart from an established interpretation of the Court of Cassation.

\section{Enforcement of judgments and orders}

Enforcement proceedings are, as one would expect, entirely separate from the underlying proceedings on the merits. A debtor may oppose enforcement on various 
grounds as we shall see later but in no way may he attempt to re-open the case on the merits.

In order to proceed with enforcement the first requirement is for the creditor to have an enforceable judgment or order or any other instrument to which enforceability is given by law.

Insofar as judgments and orders are concerned the position is as follows: sequestration orders are among those orders which by their very nature can be immediately enforced, and final judgments of Courts of First Instance are presumptively enforceable.

Foreign judgments are enforceable in the same way as a domestic judgment. The European enforcement order allows a creditor with an enforceable judgment to apply in his own member state and the order will become enforceable in every EU member state.

Before actual enforcement can take place a judgment creditor must make sure of two things: that a "certificate of enforceability" is appended to the judgment by the courts clerk who will do so only if the judgment has been declared immediately enforceable by the court or if, the judgment having been served upon the judgment debtor, no notice of appeal has been lodged with the court and the time to appeal has expired; that the judgment bearing the enforceability certificate be served again upon the judgment debtor personally (not upon his lawyer) and this is usually done together with service of the formal demand for payment to be made within a certain period of time which cannot be less than 10 days from service thereof.

The formal demand must contain a number of indications: the amount due, reference to the enforceable judgment, the domicile or residence of the creditor and the signature of the creditor or of its lawyer.

Attachment proceedings can be aimed at movable or immovable property or at sums due to the debtor by third parties. In this context, we are primarily concerned with the form of enforcement which is most widely used against a debtor. As we shall briefly see later, other forms of enforcement, whether direct or indirect, may be used against traders, businesses or companies.

In the context of enforcement against an individual debtor, attachment of goods or real property usually ends with the forcible sale of the asset and the distribution of the proceeds among all the creditors who have joined in the proceedings, unless in the meantime the debtor pays the creditor or creditors who have been parties to the proceedings. Attachment of debts can be sought by way of "garnishee" proceedings. The debtor may, of course, oppose the legitimacy of the proceedings as a whole or may object to specific steps taken during the execution proceedings or to the method of enforcement. Likewise third parties who are prejudiced by enforcement proceedings may also file an opposition which gives rise to an ordinary full trial on the merits aimed at establishing whether the alleged rights over the attached property exist (this is usually the case when the third party alleges that he is the owner of the asset).
The rules of procedure in relation to attachment, joining of other creditors, opposition by the debtor or by third parties, sale of the assets by auction or assignment to individual creditors and priority among creditors are numerous and detailed and the proceedings themselves may last for a considerable time.

It has been mentioned that in addition to attachment of assets, companies, partnerships and traders in general may be faced with an indirect form of execution of the judgment by way of bankruptcy proceedings. Mention of this procedure is made, even though it is not strictly speaking a form of enforcement of a judgment (as the existence of the judgment is not a requirement) because of the peculiarity that only trading concerns (corporations, partnerships, or sole traders) may be made subject thereto and because it is after all the last resort for a creditor who is otherwise unable to obtain redress.

There are two fundamental requirements for the obtaining of a bankruptcy judgment. One has already been stated namely that the debtor be a trader. The other consists of the state of insolvency, namely the inability to pay one's debts. Inability or unwillingness to pay a debt does not necessarily imply that a state of insolvency exists and the court will therefore look at the whole picture to ascertain whether the position of difficulty is of a temporary nature or likely to be permanent. It can therefore be seen that the existence of a judgment which cannot be disputed by the trader is already a good step towards producing to the court the necessary evidence to prove that the state of insolvency is not merely transitional.

\section{Recognition of foreign judgment and arbitration awards}

7.1. Recognition of judgments. The recognition of foreign judgments has long been established under Italian law. Presently, recognition procedures are used mainly in cases of commercial matters of a certain magnitude and in divorce cases. Formal recognition is no longer required and judgements are now automatically recognized by the Italian courts provided that certain conditions are met.

Italy will automatically recognize foreign judgments whenever:

(a) the court of the state, in which the judgment has been rendered, was able to hear the case under the Italian rules on jurisdiction;

(b) the writ of summons was served in compliance with the statutory provisions of the place where the proceedings took place, and an adequate term was given to the defendant in order to appear;

(c) the parties appeared according to the law of that state or their failure to appear was established and declared in compliance with that law;

(d) the judgment is final under the law of the state in which it has been rendered;

(e) the judgement does not conflict with an Italian judgment; 
(f) no Italian proceedings, instituted before the foreign judgment became final, on the same claim and between the same parties are pending;

(g) the judgment does not offend Italian public policy.

A claim may still, in some cases, be made to the Court of Appeal for recognition of a foreign judgement, if any of the grounds set out above are not met, or if one of the parties contests the existence of one of the grounds.

7.2. Recognition of foreign arbitral awards. The recognition of arbitral awards rendered abroad between foreign citizens or between a foreign and an Italian citizen, or between citizens domiciled or residing abroad, was substantially reformed in 1994. This new system renders more systematic the recognition and enforcement of foreign arbitral awards in accordance with the principles of the 1958 New York Convention., Recognition of a foreign arbitration award may be sought by anyone who wishes to have the award validated in Italy. Application may be made to the President of the Court of Appeal where the opposing party resides. If the opposing party is not resident in Italy then application may be made to the Court of Appeal in Rome.

The court may, by decree, declare the award effective in Italy except in cases where the award contains provisions contrary to public policy or where the dispute could not be the subject of arbitration under Italian law. Disputes concerning spouses, status of persons, political rights, personal freedom, as well as those related to contracts of employment, cannot be decided by arbitration according to Italian law.

In cases where the opposing party seeks to appear and contest the recognition of such foreign arbitration awards, application must be made to the Court of Appeal within 30 days from the date of the issuance of the decree of recognition. Jurisdiction lies with the Court of Appeal where the opposing party is resident.

The recognition or execution of the foreign award will be refused by the court if the party opposing recognition or execution proves the existence of any one of the following:

(a) the parties to the arbitration agreement, on the basis of the applicable law, lacked the capacity to enter into it, or the agreement was not valid according to the law to which the parties submitted or if no indication is given on this last point, the law of the state in which the award was made;

(b) the party against whom enforcement is sought was not informed of either the nomination of the arbitrator or the arbitration proceedings themselves or, in any case, was in a position where it was impossible to defend him or herself;

(c) the award was made with respect to an issue not covered by the pertinent arbitration clause. If, however, the issues properly decided by the arbitrator may be separated from those over which the arbitrator lacks jurisdiction, the part of the award relating to the former may be recognized and enforced;

(d) the arbitration proceedings or the constitution of the arbitration panel did not conform to the terms of the parties' agreement, or where there was no such agreement, the law of the state where the arbitration took place;

(e) the award has not yet become binding on the parties, or has been cancelled or suspended by a competent authority of the state in which or according to which it was made.

The "facilitating" rules of the New York Convention of June 10, 1957 make recognizable in Italy all foreign awards deciding disputes referable to arbitration in Italy that have been rendered pursuant to a written arbitration agreement.

The recognition is granted to the party that requests it and submits to the court the arbitration agreement and the award; a party opposing enforcement can prove to the court circumstances that, under the convention, prevent direct recognition. A rather large number of Italian court decisions deal with the problem of the proper or improper way of summoning the defendant, and one of the basic defences is that the 'foreign defendant' in the foreign country was not given the chance to understand properly that an arbitral case was being started, that he was not given sufficient time to raise his defence or that the decision was rendered in his wrongfully declared default.

7.3. Enforcement of foreign contracts and deeds. Documents, deeds, and instruments received abroad by a local public officer can be declared enforceable in Italy under the general principle, according to which the Court of Appeal, of the place where a contractual instrument received by a public officer abroad must be enforced, grants to it by judgment the strength of an enforce-able instrument, after having established that that instrument is enforceable in the foreign country in which it was received by said public officer, and that it does not offend Italian public policy.

7.4. International legislation. The enforcement of foreign judgments in Italy is governed also by several bilateral and multilateral international treaties and conventions. Examples of multilateral agreements include: The Hague Convention of 1954, the Brussels Convention on Jurisdiction and Enforcement of Judgments in Civil and Commercial Matters (signed in Brussels in 1968) and its sister Lugano Convention Council Regulation (EC) No. 44/2001 which replaces the Brussels Convention except when dealing with Denmark, but is itself a directly applicable European Regulation, rather than an international instrument. Most of the old Bilateral Treaties in Europe have been superseded by the Regulation, at least in civil and commercial matters.

\section{REFERENCES}

De Meo M., Italian Commercial Litigation. Encyclopedia of International Commercial Litigation, 2007, ed. by the Hon. Sir Anthony Colman and published by Kluver Law International and updated annually. 